\title{
Concertina effect: a subtle but specific marker
}

\author{
Vivek Singla, Bhupinder Singh, Yadvinder Singh, K Shankarappa Ravindranath
}

Sri Jayadeva Institute of Cardiovascular Sciences and Research, Bangalore, Karnataka, India

\section{Correspondence to} Dr Vivek Singla, drviveksingla98@gmail.com

\section{DESCRIPTION}

A 6-year-old boy presented with asymptomatic cardiac murmur and was diagnosed by echocardiography to have a ventricular septal defect. Electrocardiogram (figure 1A,B) showed short PR interval, $\Delta$ wave and broad QRS complex suggestive of pre-excitation through right posterior pathway. The electrocardiogram also showed variable conduction with change in cycle length with variable QRS duration and morphology but the 'P-beginning' to 'QRS—end' duration remained unchanged suggestive of 'concertina effect'.

The concertina effect is the progressive shortening of PR interval with corresponding widening of the QRS complex. ${ }^{1}$ In other words, the degree of pre-excitation demonstrates a cyclic pattern over the course of several cardiac cycles. The 'concertina' form of pre-excitation is a reasonably reliable predictor of a relatively long refractory period and thus a marker of low risk of sudden death. $^{2}$ Other non-invasive markers include intermittent pre-excitation during sinus rhythm and the abrupt loss of conduction over accessory pathway with exercise or after intravenous procainamide. These are relatively specific but not very sensitive markers of long refractory period. The most certain method is the electrophysiological study of accessory pathway for refractoriness and the ability to conduct at rapid atrial rates.

The prevalence of Wolf-Parkinson-White syndrome (symptomatic WPW pattern) in childhood is estimated to be $0.4-2.2 / 1000$ individuals. ${ }^{2}$ Although these patients usually have benign prognosis, the patients with short refractory period of

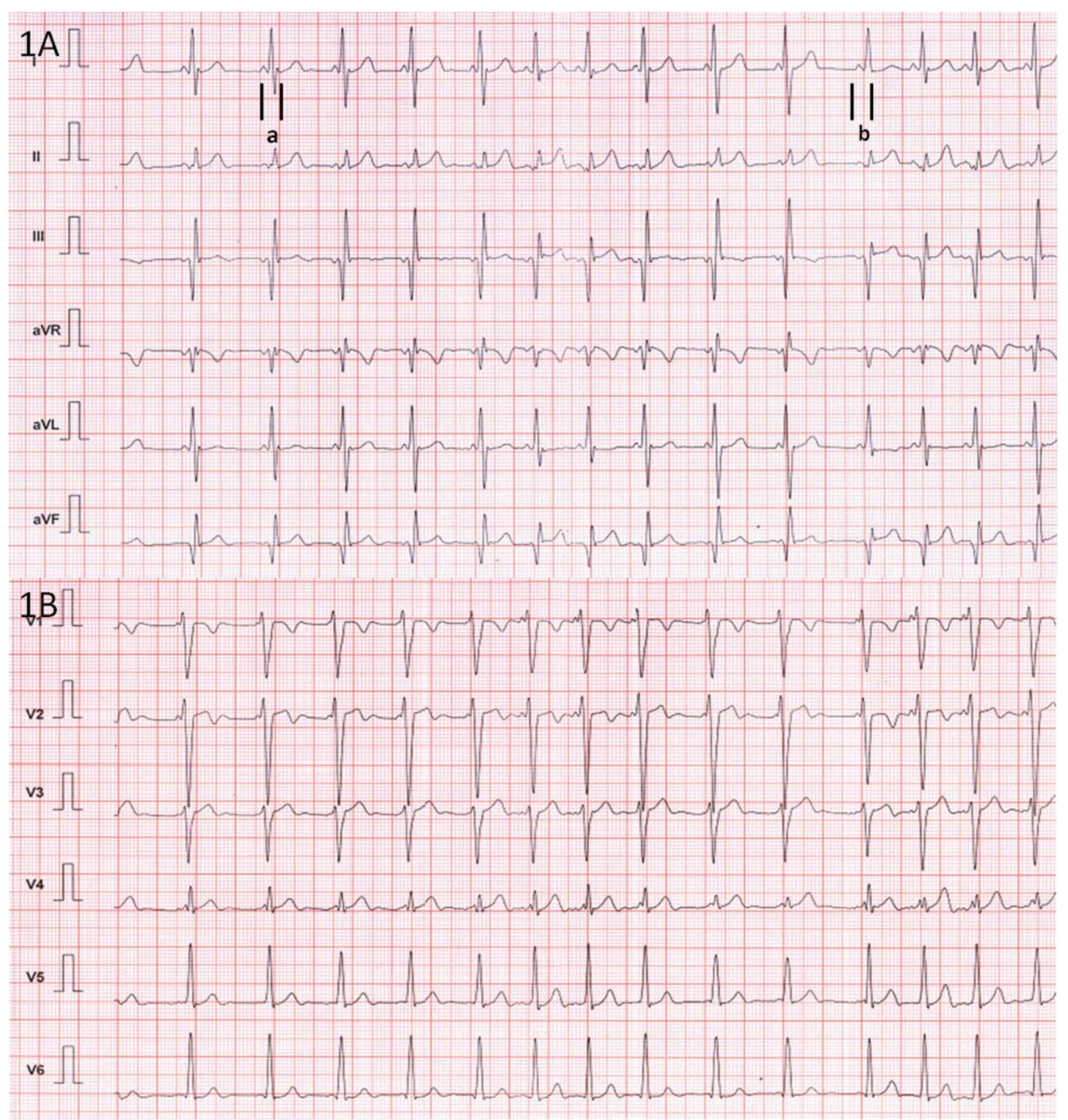

To cite: Singla $V$, Singh $B$, Singh Y, et al. BMJ Case Rep Published online:

[please include Day Month Year] doi:10.1136/bcr-2013009328
Figure 1 Electrocardiogram showing short PR interval with variable conduction (beat-to-beat change in PR interval with changing QRS morphology) over accessory pathway. Note that the 'P-beginning' to 'QRS—end' duration is same in all the complexes (eg, a, b) despite different morphology. Also there are positive $\Delta$ waves in leads I, II, aVR, aVL (A) and V1-V6 (B) with negative $\Delta$ wave in III and aVF. 
accessory pathway or multiple accessory pathways have risk of sudden death $(0.1 \%)$. The symptomatic patients and the patients with short refractory period should undergo a definite treatment in the form of radiofrequency ablation.

\section{Learning points}

- Wolf-Parkinson-White syndrome usually have benign prognosis.

- Patients with a short refractory period of accessory pathway or multiple accessory pathway's are at the risk of sudden death during an episode of supraventricular tachycardia.

- Concertina effect is a marker of long refractory period of accessory pathway.

- Radiofrequency ablation is the definitive treatment.
Competing interests None.

Patient consent Obtained.

Provenance and peer review Not commissioned; externally peer reviewed.

\section{REFERENCES}

1 Surawicz B, Knilans TK. Chou's electrocardiography in clinical practice. 6th edn. Philadelphia: Saunders Elsevier, 2008:481-508. Chapter 20, ventricular preexcitation.

2 Perez $\mathrm{M}$, Fonda $\mathrm{H}$, Le $\mathrm{V}$, et al. Adding an electrocardiogram to the pre-participation examination in competitive athletes: a systematic review. Curr Prob/ Cardiol 2009:34:586-662.

Copyright 2013 BMJ Publishing Group. All rights reserved. For permission to reuse any of this content visit http://group.bmj.com/group/rights-licensing/permissions.

BMJ Case Report Fellows may re-use this article for personal use and teaching without any further permission.

Become a Fellow of BMJ Case Reports today and you can:

- Submit as many cases as you like

- Enjoy fast sympathetic peer review and rapid publication of accepted articles

- Access all the published articles

- Re-use any of the published material for personal use and teaching without further permission

For information on Institutional Fellowships contact consortiasales@bmjgroup.com

Visit casereports.bmj.com for more articles like this and to become a Fellow 